3. World Health Organization. WHO Expert Consultation on Rabies. Second report [cited 2016 Mar 30]. http://apps.who.int/iris/ bitstream/10665/85346/1/9789240690943_eng.pdf

4. World Health Organization. Rabies vaccines: WHO position paper. Wkly Epidemiol Rec. 2010;85:309-20 [cited 2017 Oct 5]. http://www.who.int/wer/2010/wer8532/en/

5. Rupprecht CE, Hanlon CA, Hemachudha T. Rabies re-examined. Lancet Infect Dis. 2002;2:327-43. http://dx.doi.org/10.1016/ S1473-3099(02)00287-6

6. Vigilato MAN, Clavijo A, Knobl T, Silva HMT, Cosivi O, Schneider MC, et al. Progress towards eliminating canine rabies: policies and perspectives from Latin America and the Caribbean. Philos Trans R Soc Lond B Biol Sci. 2013;368:20120143. http://dx.doi.org/10.1098/rstb.2012.0143

7. Wallace RM, Undurraga EA, Blanton JD, Cleaton J, Franka R. Elimination of dog-mediated human rabies deaths by 2030: needs assessment and alternatives for progress based on dog vaccination. Front Vet Sci. 2017;4:9. http://dx.doi.org/10.3389/fvets.2017.00009

8. Lembo T, Hampson K, Kaare MT, Ernest E, Knobel D, Kazwala RR, et al. The feasibility of canine rabies elimination in Africa: dispelling doubts with data. PLoS Negl Trop Dis. 2010;4:e626. http://dx.doi.org/10.1371/journal.pntd.0000626

9. Republic of Kenya Ministry of Health and Ministry of Agriculture. Strategic plan for the elimination of human rabies in Kenya 2014-2030 [cited 2017 Jun 1]. http://zdukenya.org/wp-content/ uploads/2012/09/National-Rabies-Elimination-Strategy.pdf

10. Zinsstag J, Dürr S, Penny MA, Mindekem R, Roth F, Menendez Gonzalez S, et al. Transmission dynamics and economics of rabies control in dogs and humans in an African city. Proc Natl Acad Sci U S A. 2009;106:14996-5001. http://dx.doi.org/ 10.1073/pnas.0904740106

Address for correspondence: Eduardo A. Undurraga, School of Government, Pontificia Universidad Católica de Chile, Vicuña Mackenna 4860, Macul CP 7820436, Región Metropolitana, Chile; email: eundurra@uc.cl

\section{Unexpected Infection with Armillifer Parasites}

\author{
Idzi Potters, Claude Desaive, \\ Steven Van Den Broucke, \\ Marjan Van Esbroeck, Lutgarde Lynen
}

Author affiliations: Institute of Tropical Medicine Antwerp, Antwerp, Belgium (I. Potters, S. Van Den Broucke, M. Van Esbroeck, L. Lynen); Central University Hospital of Liège, Liège, Belgium (C. Desaive)

DOI: https://doi.org/10.3201/eid2312.171189

Visceral pentastomiasis is usually found incidentally during surgery. We describe a case of visceral pentastomiasis discovered during inguinoscrotal hernia surgery for a man from Benin, Africa. Because surgical removal of nymphs is needed for symptomatic patients only, this patient's asymptomatic pentastomiasis was not treated and he recovered from surgery uneventfully.

$\mathrm{I}^{\mathrm{n}}$ n November 2015, a surgeon from Belgium, working for Medics without Vacation in Bassila, Benin, Africa, incidentally discovered pentastomiasis in an adult man during surgery for a massive inguinoscrotal hernia (half a liter content). Other than the hernia, the patient had no health problems. During the procedure, the surgeon observed at least 10 coiled, larva-like structures on the patient's peritoneal tissue. He removed the hernial sac and sent a tissue specimen to the national reference laboratory for parasitology at the Institute of Tropical Medicine (Antwerp, Belgium) for identification of the parasite. Apart from the hernia symptoms, the patient was asymptomatic, so the parasites were not removed; the patient's surgical recovery was uneventful.

Macroscopic examination of the peritoneal tissue detected 8 distinct, typical larva-like structures with an average length of 1-2 $\mathrm{cm}$ (Figure, panel A). Because the structures were suspected to be pentastomes, they were compared with reference material from the Institute of Tropical Medicine Educational Department (Figure, panel B) and confirmed as Armillifer spp. nymphs. On the basis of the patient's residence in Benin, and the fact that the recovered nymphs consistently exhibited $<22$ annuli, the structures were presumptively identified as $A$. armillatus $(1,2)$. Adults of this species are often found in the respiratory system of large snakes. Although no information was available regarding the patient's contact with snakes, the presence of this parasite in a resident of Benin is not surprising because snake consumption in that country is common practice. The patient's surgeon confirmed that dead snakes were indeed often sold for consumption along the streets near the hospital.

The Pentastomida are a peculiar group of gonochoric, vermiform endoparasites, currently classified as a unique phylum, related to branchiuran crustaceans (3). The main characteristics of this group of ancient parasitic arthropods are an often annulated elongate body and a mouth typically flanked by 2 pairs of hooks.

Human visceral pentastomiasis can be caused by several species of pentastomes: Linguatula serrata (worldwide, predominantly the Middle East), A. armillatus (West and Central Africa), A. moniliformis (Southeast Asia), A. grandis (Africa), A. agkistrodontis (China), Porocephalus crotali (worldwide, predominantly the Americas), and P. taiwana (China) $(2,4,5)$. Reported cases of human visceral pentastomiasis were caused mainly by $A$. armillatus pentastomes ( 6 ) from infected snakes, which shed ova in excretions and respiratory secretions, thereby 

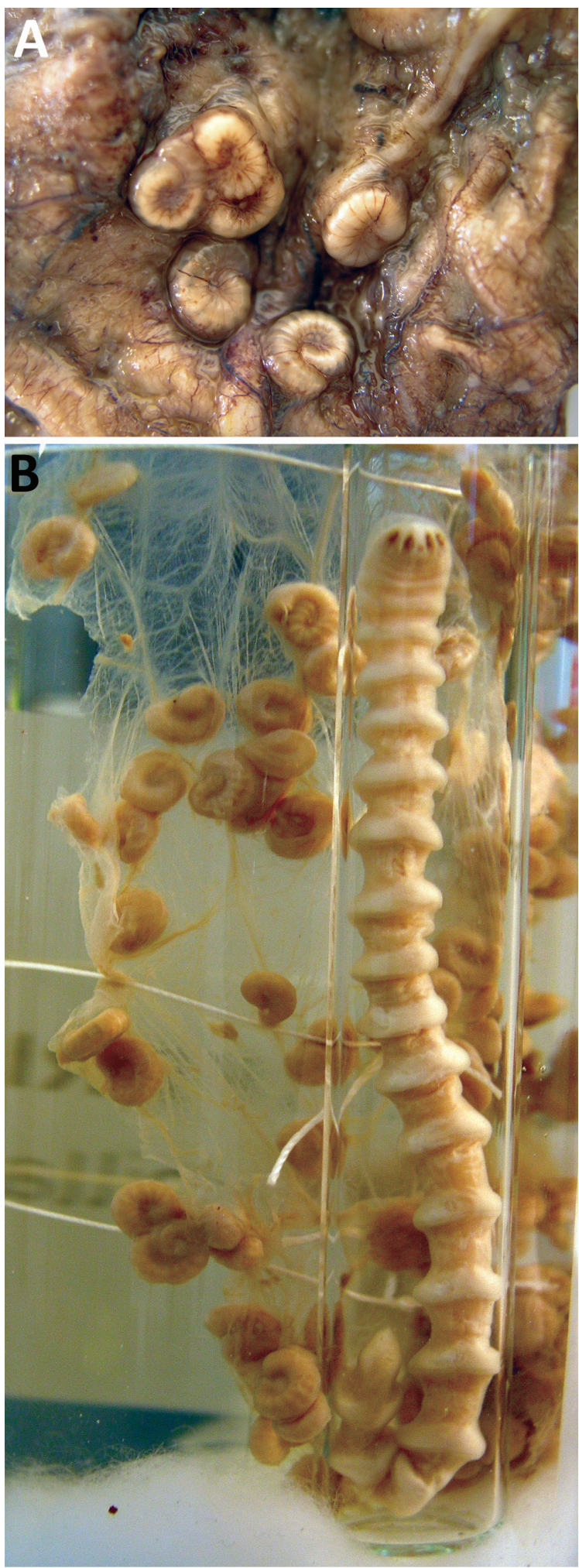

Figure. Armillifer armillatus parasites. A) Typically coiled Armillifer armillatus nymphs, averaging $1-2 \mathrm{~cm}$ long and consistently showing <22 annuli. B) Adult female and numerous nymphs. Reference material from the Educational Department, Institute of Tropical Medicine, Antwerp, Belgium. contaminating vegetation and water. Intermediate hosts are mainly rodents and small mammals. After oral uptake by the intermediate host, the ova hatch and free 4-legged primary larvae that migrate to the viscera, become encapsulated, and after several molts transform into legless nymphs $(2,7)$. The cycle is complete when the intermediate host is in turn consumed by a snake of an appropriate species. Humans can become intermediate hosts through ingestion of environmental ova, by eating undercooked infected snake meat, or by oral uptake of ova when in close contact with snakes $(1,2,6)$. Diagnosis of human visceral pentastomiasis is classically made by either identifying the nymphs during autopsy or surgery or by discovering typically crescentic or coiled opacities, representing calcified dead larvae, on abdominal or chest radiographs.

The finding of pentastomiasis in patients with inguinal hernia, as with the patient reported here, has been described for 2 patients in Ghana (8). The number of reported cases of human pentastomiasis from Africa is increasing $(6,8)$; because infection with Armillifer parasites is usually asymptomatic, we assume that the incidence of this infection is underestimated. Autopsy studies have reported prevalence rates as high as $22 \%$ in the Democratic Republic of the Congo and $45 \%$ in Malaysia $(9,10)$. As industrialized countries are increasingly receiving immigrants and refugees from Africa, it is conceivable that this disease will be more frequently encountered.

Because pentastomes are usually not mentioned in the helminth section of parasitology textbooks, laboratory technicians, clinicians, and surgeons who are unfamiliar with this parasite might be startled when incidentally discovering it. They should note that visceral pentastomiasis is usually asymptomatic and that surgical removal of the nymphs should be considered only for symptomatic patients with high parasite loads. No medical treatment is available.

\section{Acknowledgments}

We gratefully acknowledge the excellent laboratory assistance provided by Hilde Cox and Henk Vereecken.

Mr. Potters works at the national reference laboratory for parasitology at the Institute of Tropical Medicine, Antwerp, Belgium. His research interest is tropical parasitology. He regularly coordinates, organizes, and lectures at workshops on parasitology, including diagnostic techniques for parasitology.

\section{References}

1. Tappe D, Haeupler A, Schäfer H, Racz P, Cramer JP, Poppert S. Armillifer armillatus pentastomiasis in African immigrant, Germany. Emerg Infect Dis. 2013;19:507-8. http://dx.doi.org/ 10.3201/eid1903.121508

2. Tappe D, Büttner DW. Diagnosis of human visceral pentastomiasis. PLoS Negl Trop Dis. 2009;3:e320. http://dx.doi.org/10.1371/ journal.pntd.0000320 
3. Lavrov DV, Brown WM, Boore JL. Phylogenetic position of the Pentastomida and (pan)crustacean relationships. Proc Biol Sci. 2004;271:537-44. http://dx.doi.org/10.1098/rspb.2003.2631

4. Yao MH, Wu F, Tang LF. Human pentastomiasis in China: case report and literature review. J Parasitol. 2008;94:1295-8. http://dx.doi.org/10.1645/GE-1597.1

5. Latif B, Omar E, Heo CC, Othman N, Tappe D. Human pentastomiasis caused by Armillifer moniliformis in Malaysian Borneo. Am J Trop Med Hyg. 2011;85:878-81. http://dx.doi.org/ 10.4269/ajtmh.2011.11-0404

6. Tappe D, Meyer M, Oesterlein A, Jaye A, Frosch M, Schoen C, et al. Transmission of Armillifer armillatus ova at snake farm, The Gambia, West Africa. Emerg Infect Dis. 2011;17:251-4. http://dx.doi.org/10.3201/eid1702.101118

7. Meyers WM, Neafie RC, Connor DH. Pentastomiasis. In: Binford $\mathrm{CH}$, Connor DH, editors. Pathology of tropical and extraordinary diseases. Washington (DC): Armed Forces Institute of Pathology; 1976. p. $546-50$.

8. Dakubo JCB, Etwire VK. Human pentastomiasis in upper east region of Ghana: report of two cases. Postgrad Med J Ghana. 2014;3:56-60.

9. Mouchet R. Note sur Porocephalus moniliformis. Bull Soc Path exot. 1914;7:497-501.

10. Prathap K, Lau KS, Bolton JM. Pentastomiasis: a common finding at autopsy among Malaysian aborigines. Am J Trop Med Hyg. 1969;18:20-7. http://dx.doi.org/10.4269/ajtmh.1969.18.20

Address for correspondence: Idzi Potters, Department of Clinical

Sciences, Institute of Tropical Medicine Antwerp, Kronenburgstraat 43/3, 2000 Antwerp, Belgium; email: ipotters@itg.be

\section{Influenza A(H9N2) Virus, Burkina Faso}

\section{Bianca Zecchin, ${ }^{1}$ Germaine Minoungou, ${ }^{1}$ Alice Fusaro, Sidi Moctar, Anne Ouedraogo-Kaboré, Alessia Schivo, Annalisa Salviato, Sabrina Marciano, Isabella Monne}

Author affiliations: Istituto Zooprofilattico Sperimentale delle Venezie, Legnaro, Padova, Italy (B. Zecchin, A. Fusaro, A. Schivo, A. Salviato, S. Marciano, I. Monne); Laboratoire National d'Elevage de Ouagadougou, Ouagadougou, Burkina Faso (G. Minoungou, S. Moctar, A. Ouedraogo-Kaboré)

DOI: https://doi.org/10.3201/eid2312.171294

We identified influenza $A(H 9 N 2)$ virus $\mathrm{G} 1$ lineage in poultry in Burkina Faso. Urgent actions are needed to raise awareness about the risk associated with spread of this zoonotic virus

${ }^{1}$ These authors contributed equally to this article. subtype in the area and to construct a strategy for effective prevention and control of influenza caused by this virus.

Since their detection in China in 1992, influenza $\mathrm{A}_{\text {A(H9N2) viruses have caused large economic losses to }}$ the poultry industry and have occasionally been transmitted to mammalian species, including humans. Three main genetic lineages were described among the Eurasian H9N2 subtype viruses: G1, Y280, and Y439 (Korean) lineage (1). In the past decade, the G1 lineage has spread mostly in gallinaceous birds across Asia, the Middle East, and eventually North Africa, where H9N2 outbreaks were reported in Libya (2006 and 2013) (2), Tunisia (2010-2012) (3), Egypt (2011-present), and Morocco (2016) (4).

The Veterinary Services of Ouagadougou, Burkina Faso, submitted 30 tracheal swab specimens and 10 organ samples collected in January 2017 in Burkina Faso to the World Organisation for Animal Health/Food and Agriculture Organization of the United Nations Reference Laboratory for Avian Influenza, Istituto Zooprofilattico Sperimentale delle Venezie (Legnaro, Padova, Italy). All samples were collected from a layer farm that was experiencing decreased egg production and respiratory signs among its flock; the animals were suspected to have infectious bronchitis virus (IBV).

Molecular analyses of the animal samples showed negative results for IBV and indicated that animals from the farm were infected with avian influenza $A(H 9 N 2)$ virus. The 8 gene segments were obtained for 1 representative virus by using a MiSeq Platform (Illumina, San Diego, CA, USA). Sequences were submitted to GenBank under accession numbers MF510849-56.

The maximum-likelihood phylogenetic tree of the hemagglutinin (HA) gene showed that the H9N2 subtype virus from Burkina Faso belonged to the G1 lineage, which has remarkable zoonotic potential. This virus clustered with H9N2 subtype viruses isolated in Morocco in 2016 (99.2\% similarity) and with an H9N2 subtype virus identified in the United Arab Emirates in 2015 (A/chicken/ Dubai/D2506.A/2015) (98.7\% similarity) (online Technical Appendix Figure 1, https://wwwnc.cdc.gov/EID/ article/23/12/17-1294-Teachapp1.pdf). Phylogenetic trees obtained for all other gene segments confirmed clustering with viruses from Morocco and the United Arab Emirates, similar to that observed for HA gene phylogeny.

Phylogeographic analysis (online Technical Appendix) identified multiple introductions of influenza A(H9N2) virus into North Africa from the Middle East and Pakistan. The H9N2 subtype virus identified in Burkina Faso seems to have originated from Morocco, although we cannot rule out the possibility that H9N2 subtype viruses were circulating in unsampled locations (online Technical Appendix Figure 2, Video, https://wwwnc.cdc.gov/EID/article/23/12/171294-V1.htm). 